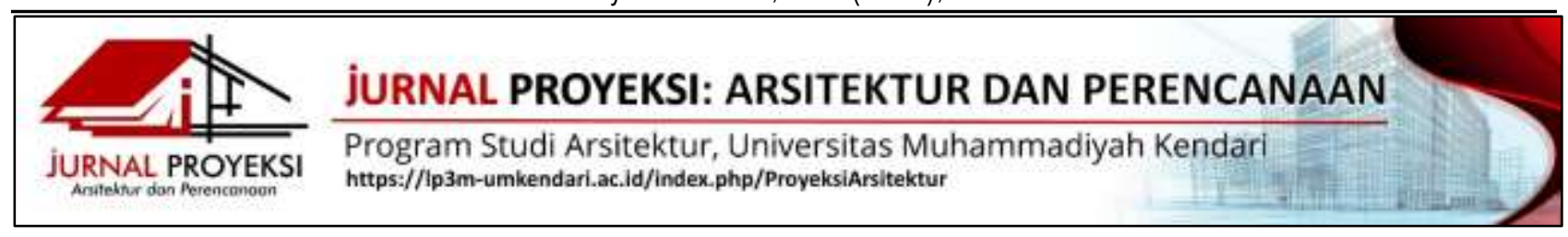

\title{
PENERAPAN ARSITEKTUR MODERN PADA PERENCANAAN APARTEMEN DI KOTA KENDARI
}

\author{
Syukur ${ }^{1}$, Hapsa Riyanti ${ }^{2}$, Yudhi Dwi Hartono ${ }^{3^{*}}$ \\ 1,3 Program Studi Arsitektur, Fakultas Teknik, Universitas Muhammadiyah Kendari \\ 2 Jurusan Arsitektur, Fakultas Teknik, Universitas Halu Oleo \\ *yudhi@umkendari.ac.id
}

\author{
INFORMASI ARTIKEL \\ Diterima Redaksi: \\ 11 Agustus 2021 \\ Revisi Akhir: \\ 07 September 2021 \\ Diterbitkan: \\ Cetak: \\ 19 September 2021 \\ Online \\ 19 September 2021
}

\section{Abstract}

Kendari City is one of the developing cities in Indonesia with a modern type of society that tends to expect practicality and time efficiency. A typical society like this needs to be accommodated by the existence of vertical housing. Phenomena and opportunities like this need to be addressed wisely by the local government and business people in the property sector. Therefore, the City of Kendari needs to plan a residence that is arranged vertically in this case an apartment as a solution to the current high demand for housing. To be able to plan a good apartment, this study uses a descriptive qualitative method combined with a quantitative approach. Based on the results of location and site analysis, this apartment building is planned to be built in Kadia District, Kendari City. The concept or theme applied to the planning of this building is a modern concept that is the unity and characteristic of apartment buildings. With the planning and design of an apartment building with a modern concept, it is hoped that this apartment can meet the needs of the community as an upper middle class residence and become a new Landmaerk in Kendari City.

Keywords: Apartment Planning, Modern Architecture, Kendari City

\section{Abstrak}

Kota Kendari merupakan salah satu kota berkembang di Indonesia dengan tipe masyarakat modern yang cenderung mengharapkan kepraktisan dan efesiensi waktu. Tipikal masyarakat seperti ini perlu diwadahi dengan keberadaan hunia vertikal. Fenomena serta peluang seperti ini perlu disikapi secara bijak oleh pemerintah daerah maupun pelaku bisnis dalam bidang properti. Oleh karena itu, Kota Kendari perlu merencanakan suatu hunian yang disusun secara vertikal dalam hal ini Apartemen sebagai salah satu solusi akan kebutuhan hunian yang cukup tinggi saat ini. Untuk dapat merencanakan apartemen yang baik, penelitian ini menggunakan metode qualitatif deskriptif yang dikombinasikan dengan pendekatan quantitatif. Berdasarkan hasil pengolahan lokasi dan tapak, gedung apartemen ini direncanakan akan dibangun di Kecamatan Kadia, Kota Kendari. Konsep atau tema yang diterapkan pada perencanaan gedung ini merupakan konsep modern yang menjadi kesatuan dan ciri dari bangunan apartemen. Dengan adanya perencanaan dan perancangan gedung apartemen dengan konsep modern, diharapkan apartemen ini dapat memenuhi kebutuhan masyarakat sebagai hunian kelas menengah ke atas serta menjadi Landmaerk baru di Kota Kendari.

Kata Kunci: Perencanaan Apartemen, Arsitektur Modern, Kota Kendari

\section{PENDAHULUAN \\ Latar Belakang}

Kendari adalah ibu kota Provinsi Sulawesi Tenggara (Sultra), Indonesia yang diresmikan sebagai kotamadya (kini kota) dengan UU RI No. 6 Tahun 1995 tanggal 27 September 1995. Kota ini memiliki luas 296,000 $\mathrm{km}^{2}(29.600 \mathrm{Ha})$. Berdasarkan jumlah penduduk Kota Kendari, kepadatan penduduk Kecamatan dan Kepemilikan Kartu Tanda Penduduk (KTP) di Tahun 2014 sebanyak 162.043 jiwa, di tahun 2015 sebanyak
170.529 jiwa dan di Tahun 2016 sebanyak 181.103 jiwa. Dari data tersebut Kota Kendari mengalami peningkatan jumlah penduduk yang cukup pesat setiap tahunnya sehingga permintaan akan hunian penduduk mengalami peningkatan. (BPS. Kota Kendari, 2017)

Kota Kendari memiliki perkembangan yang cukup pesat salah satunya tingkat populasi penduduk yang semakin meningkat. Banyaknya pendatang dari berbagai daerah bertujuan untuk mencari pekerjaan di Kota Kendari. Hal ini 
membuat permintaan akan hunian semakin meningkat setiap tahunya (proyeksi penduduk 2010-2035)

Melihat dari banyaknya tingkat presentasi kepadatan penduduk setiap tahunnya, pada Tahun 2018 Real Estate Indonesia (REI) Sultra menargetkan pembangunan 3.500 unit rumah agar mampu mengatasi laju pertumbuhan penduduk Kota Kendari yang cuckup pesat perkembanganya. Sementara jumlah hunian yang terbangun pada tahun 2017 mempunyai target 1.285 dan jumlah yang terbangun pada tahun 2017 adalah 985 unit hunian. Dan yang belum terbangun mencapai 300 unit hunian. Target tersebut belum menyampai target yang telah disetujui oleh pemerinta (REI Sultra, 2018)

Apartemen merupakan hunian yang tidak sekedar menjadi tempat bernaung, tetapi dapat memfasilitasi penguhuninya dalam berbagai aktifitas, kini telah menjadi salah satu pilihan dari masyarakat modern di Kota-Kota yang sedang berkembang. Tipekal masyarakat modern yang mengharapkan kepraktisan dan efesien waktu yang disertai dengan kultur masyarakat perkotaan yang serba cepat dapat terwadahi dengan keberadaan hunian vertikal yang kemudian mejamur di pusat Kota dan distrik komersial yang berkembang menjadi investasi, wadah dan gaya hidup pemakainya.

karena pembangunan Apartemen mempertimbangkan keperaktisan, keamanan, keprivasiann dan juga karena dan masalah pristige. Oleh karena itu, apartemen yang dibuat memang tidak diharapkan akan diminati dan dihuni oleh semua kalangan, melainkan untuk kalangan tertentu saja. Dalam hal ini kalangan yang pada umumnya mempunyai sifat dan budaya yang cenderung individualisme yaitu kalangan menengah keatas dan para pekerja/investor asing.

Berkaitan dengan masalah tata ruang, pemerintahan telah memberikan alternatif pemecahan dengan mengalokasikan wilayah pinggiran kota sebagai zona pembangunan perumahan standar yang kemudian dikembangkan sendiri oleh pemiliknya, dengan pengembangan ke Barat dan Selatan Kota Kendari, pada bagian Barat yang merupakan pusat pembangunan kota diperuntuhkan pada bangunan-bangunan ke arah vertikal. Salah satu bentuk bangunan vertikal yang dapat dibangun di Kota Kendari adalah apartemen, karena pada dasarnya perencanaan apartemen adalah suatu bentuk lingkungan di dalam kota dimana fasilitas dan masyarakat penghuninya dapat berdampingan dengan sektor perdagangan dan jasa, serta dapat saling menunjang eksitensinya dan berintegrasi satu sama lain.

Dengan adanya suatu acuan perancangan gedung Apartemen yang ditinjau dari segi arsitektural, maupun dari segi fungsi dan rencana perkembanganya, maka diharapakan disamping akan menjadi Landmark baru di Kota kendari, proyek ini juga dapat mengatasi dan membantu sebagian masalah pemerintah dalam memenuhi kebutuhan masyarakat akan hunian dan turut serta mendukung program pemerintah dalam pemerataan pembanggunan di segala bidang.

Berdasarkan pertimbangan-pertimbangan di atas, maka hal inilah yang melatarbelakangi perencanaan apartemen ini. Bangunan ini didesain untuk mewadahi tingginya permintaan hunian, sebagai solusi pembangunan hunian vertikal di tengah padatnya pemukiman dan sarana perekonomian yang tidak tertata serta didukung dengan fasilitas-fasiltas penunjang sehingga menjadi daya tarik tersendiri bagi calon penghuni apartemen di Kota Kendari.

\section{A. Pertanyaan Penelitian}

Berdasarkan pada uraian latar belakang di atas, peneliti merumuskan pertanyaan penelitian yang ingin diketahui antara lain:

1. Bagaimana menentukan lokasi yang strategis agar perencanaan Apartemen di Kota Kendari dapat memenuhi fungsi dan kebutuhan?

2. Bagaimana mendesain gedung Apartemen yang mengadopsi Arsitektur moderen?

\section{B. Tujuan Pembahasan}

Adapun tujuan dari pembahasan yang akan dicapai yaitu:

1. Menentukan lokasi yang strategis agar perencanaan Apartemen di Kota Kendari dapat memenuhi fungsi dan kebutuhan.

2. Mendesain gedung Apartemen yang mengadopsi Arsitektur Modern.

C. Sasaran dan Batasan Pembahasan

1. Adapun sasaran pembahasan penelitian ini adalah tersusunnya konsep dasar dan landasan program Apartemen di Kota Kendari dengan Penekanan Arsitektur Moderen, menentukan lokasi yang strategis agar perencanaan Apartemen di Kota Kendari dapat memenuhi fungsi dan kebutuhan serta mendesain gedung Apartemen yang mengadopsi Arsitektur Modern

2. Batasan pembahasan bertujuan untuk memberikan batasan yang jelas untuk mengarahkan penulisan/perencanaan. Pembatasan ini dibatasi pada masalah yang nantinya diharapkan dapat menghasilkan acuan perencanaan yang sesuai dengan karakter.

\section{TINJUAN PUSTAKA}

\section{A. Tinjauan Apartemen}

Apartemen dibangun untuk memenuhi kebutuhan hunian masyarakat menengah ke atas sedangkan rumah susun dibangun untuk kebutuhan rumah kelas ekonomi menengah ke bawah. Jika dilihat dari tinggkat privasi apartemen sangat tinggi, sedangkan tingkat privasi di unit rumah susun masih sangat rendah. Kamar atau beberapa kamar (ruangan) yang diperuntukan sebagai tempat tinggal, terdapat suatu bangunan yang biasanya mempunyai kamar atau ruangan-ruangan yang lain semacam itu (Poerwaedaminta, 1991). Apartemen juga didefinisikan sebagai gedung bertingkat yang dibangun dalam suatu lingkungan yang terbagi atas 
bagian-bagian yang distrukturkan secara fungsional dalam arah vertikal dan horizontal dan merupakan satuan-satuan yang dapat dimiliki dan digunakan secara terpisah yang dilengkapi dengan bagian bersama, tanah bersama, dan benda bersama. (Pasal 1 UURS no.16 tahun 1985).

\section{B. Fungsi dan Karakteristik Apartemen}

Fungsi utama yaitu fungsi dominan dalam sebuah apartemen adalah pemukiman. Apartemen mempunyai ruang-ruang yang mewadahi aktifitasaktifitas penghuni yang berlangsung secara rutin jenis aktifitas tersebut antara lain tidur, makan, menerima tamu, berinteraksi sosial, melakukan hobi, bekerja dan lain-lain. Sementara itu, karakteristik apartemen dapat dilihat dari ciri-cirinya sebagai berikut:

1. Memilik lebih dari dua lantai dan biasanya bangunan berbentuk vertikal.

2. Dalam satu lantai terdiri dari unit-unit hunian.

3. Fleksibel dalam mencapai pemanfaatan ruang secara maksimal.

4. Efesien, efektif, dan ekonomis.

5. Memiliki fasilitas bersama yang belum tentu dimiliki perumahan.

6. Pada umumnya terdapat area komersil pada bangunan atau lingkungan apartemen.

7. Sirkulasi vertikal berupa tangga atau lift dan sirkulasi horizontal berupa koridor.

8. Keamanan, ketenangan, dan privasi lebih terjamin.

9. Akses yang mudah dan cepat untuk menjangkau fasilitas-fasilitas yang ada.

10.Struktur pada bahan bangunan dapat bertahan dalam jangka waktu yang lama.

\section{Arsitektur Modern}

Arsitektur Modern adalah suatu istilah yang diberikan kepada sejumlah bangunan dengan gaya karakteristik yang mengutamakan kesederhanaan bentuk dan menghapus segala macam ornamen. Karakter ini disinyalir pertama muncul pada sekitar tahun 1900. Pada tahun 1940 gaya ini telah diperkuat dan dikenali dengan Gaya Internasional dan menjadi bangunan yang dominan untuk beberapa dekade dalam abad ke-20 ini.

\section{Prinsip-prinsip Arsitektur Modern}

Arsitektur Modern memiliki beberapa prinsip, di antaranya:

a. Sistem firmitas atau sistem kekokohan, dimana tiang dan lantai merupakan satu kesatuan atau saling mengikat, ada pondasi dan penghubung lantai dasar sebagai pengikat konstruksi. Jadi pada arsitektur modern ini lebih menonjolkan pada bentuk-bentuk yang dianggap kokoh.

b. Adanya penggunaan bahan hasil pabrikasi untuk penutup atau kulit bangunan. Karena adanya revolusi industri yang banyak menyebabkan penggunaan bahan-bahan pabrik menjadi tren saat itu. Bahan-bahan yang banyak digunakan pada saat itu yaitu bahan-bahan baru seperti besi, baja, beton dan kaca. Para arsitek pada saat itu sednag gemar-gemarnya menggunakan bahan-bahan ini.

c. Terdapat sistem grid pada denah, tidak mempunyai pusat tertentu dan bentuknya biasanya asimetri. Disini denah sudah lebih kaya akan bentuk dan tidak berbentuk simetris seperti pada denah-denah bangunan beraliran klasik sebelumnya. Dan tidak mempunyai pusat-pusat tertentu.

d. Selalu ada bukaan-bukaan (lubang-lubang) karena pada saat itu arsitek sudah mulai memikirkan bagaimana menciptakan bangunan yang sehat yang diantaranya dengan menggunakan banyak bukaan-bukaan (lubanglubang) sebagai sirkulasi udara agar udara lebih nyaman di dalamnya.

e. Alam dipinjam (dipasang) agar telihat sebagai ornamen tapi tidak menjadi bagian dari bangunan. Di bangunan-bangunan modern penggunaan tanaman-tanaman hias merupakan pengganti dari ornamen-ornamen estetis yang terdapat pada bangunan aliran sebelumnya.

f. Adanya kontak dengan alam baik secara langsung ataupun secara tidak langsung. Alam disini mulai diperhatikan kembali sebagai unsur yang penting baik itu sebagai penunjang kenyamanan maupun kesehatan lingkungan bangunan.

g. Ada keinginan akan sebuah lingkungan yang sehat, jarak antar bangunan berjauhan. Telah saya jelaskan diatas bahwa arsitek beraliran modern mulai kembali memperhatikan kesehatan bangunan salah satunya juga dengan cara memperjauh jarak antar bangunan disamping juga sebagai penambah unsur keindahan dari bangunan itu sendiri lepas dari bangunan-banguna lain disekitarnya.

\section{METODOLOGI PENELITIAN}

Penelitian ini menggunakan pengamatan langsung, pengumpulan data dengan observasi langsung atau dengan pengamatan langsung adalah cara pengambilan data dengan menggunakan mata tanpa ada pertolongan alat standar lain untuk keperluan tersebut.

Serta Penelitian ini menggunakan studi literatur, melalui literatur-literatur dan buku-buku yang berkaitan dengan pembahasan untuk mendapatkan teori proses perancangan.

Untuk mencapai semua tujuan penilitian, peneliti perlu menentukan secara tepat jenis data atau informasi yang dibutuhkan karena dapat membantu peneliti menciptakan pertanyaanpertanyaan dengan kategori respon yang sesuai. Berguna bagi perancang survei untuk memikirkan pertanyaan sebagai pengumpulan informasi dari kategori utama yakni opini, sikap, dan motif; kepercayaan dan persepsi, perilaku, fakta dan atribut, dan pengetahuan (Ulber Silalahi, 2018). 


\section{HASIL PENELITIAN DAN PEMBAHASAN}

\section{A. Lokasi Proyek}

1. Nama Proyek : Apartemen Di Kota Kendari

2. Lokasi Proyek : Di Kota Kendari, Kec. Kadia

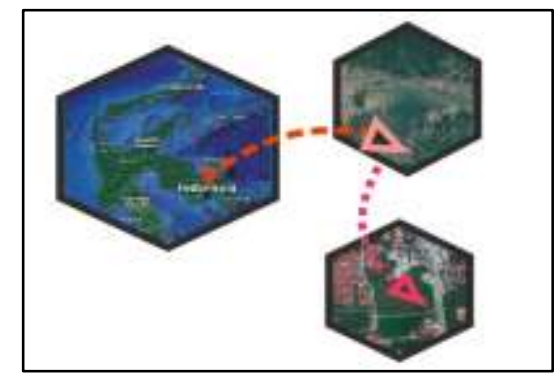

Gambar 1 Lokasi Perencanaan Apartemen (Sumber: Google Earth 2019)

3. Batas-batas Tapak

a. Sebelah utara : pemukiman dan pertokoan

b. Sebelah timur : pemukiman pertokoan dan pendidikan

c. Sebelah slatan : pemukiman dan pasar

d. Sebelah barat : pemukiman dan pendidikan

\section{B. Konsep Pengolahan Tapak}

1. Orientasi Matahari dan Angin

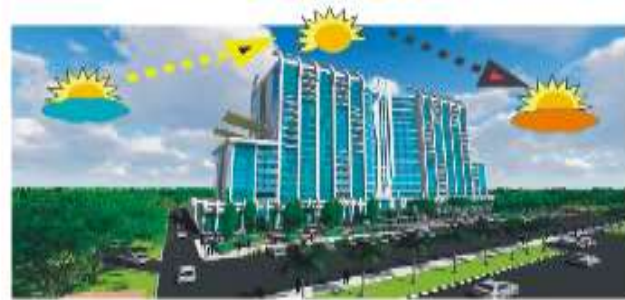

Gambar 2. Analisis Orientasi Matahari (Sumber : Analisis Penulis, 2020)

Untuk efisiensi dan kenyamanan optimal yang berkaitan dengan panas dan cahaya matahari dilakukan perencanaan sebagai berikut:

a. Memposisikan orientasi bangunan yaitu orientasi menyangkut posisi bangunan pada site dimana arah memanjang dihadapkan ke arah utara dan selatan.

b. Penggunaan material yang bisa menyerap panas, khususnya pada bagian bagunan yang berpotensi mendapat sinar matahari paling banyak

c. Penanaman vegetasi sebagai sun-shading pada lansekap.

d. Penggunaan ornamen yang bisa berfungsi ganda, bukan hanya sebagai faktor estetika tetapi sebagai shadding sinar matahari

e. Memaksimalkan sinar matahari sebagai sumber pencahayaan alami dengan menggunakan dinding kaca.

2. Kebisingan

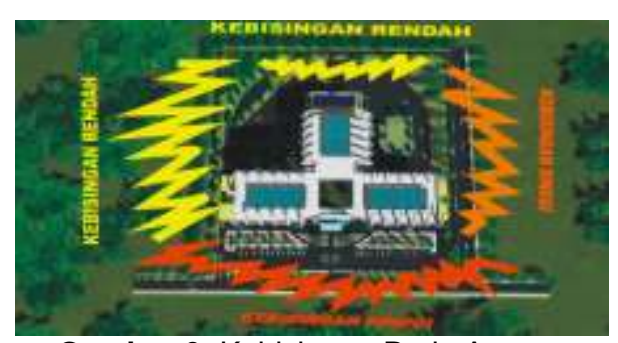

Gambar 3. Kebisingan Pada Apartemen (Sumber : Analisis Penulis, 2020)

Kebisingan merupakan efek suara yang dihasilkan oleh banyak faktor seperti suara yang berasal dari kendaraan. Untuk mengurangi kebisingan tersebut ada beberapa cara yang dapat diterapkan yaitu :

a. Pengaturan jarak bangunan dengan jalan

b. Panggunaan pohon yang tepat serta pengaturan jarak pohon pada tapak

c. Penggunaan material akustik bangunan

3. Curah Hujan

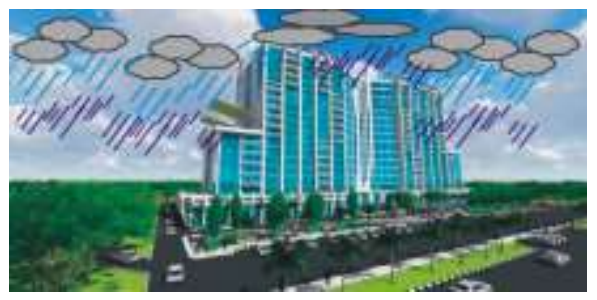

Gambar 4. Analisis Curah Hujan

(Sumber: Analisis Penulis, 2020)

Dengan tingkat intensitas curah hujan yang cukup tinggi di Kota Kendari, maka akan mempengaruhi model dan konstruksi struktur atap bangunan serta pemilihan material yang akan diaplikasikan kebangunan. Untuk itu maka pendekatan yang digunakan yaitu:

a. Kemiringan atap sedang untuk memudahkan pengaliran air hujan.

b. Penerapan green roof sebagai salah satu teknologi dari arsitektur berkelanjutan.

c. Finishing permukaan tanah diberikan permainan ketinggian untuk menyalurkan air ke ruang water tank bawah dan disalurkan ke ruang ruang untuk dimanfaatkan kembali seperti untuk menyiram kloset, urinoir dan RTH.

d. Penggunaan teknologi biopori sebagai salah satu alternatif untuk menghindari terjadinya genangan air pada saat musim penghujan dan dialirkan ke tanah.

4. Penzoningan

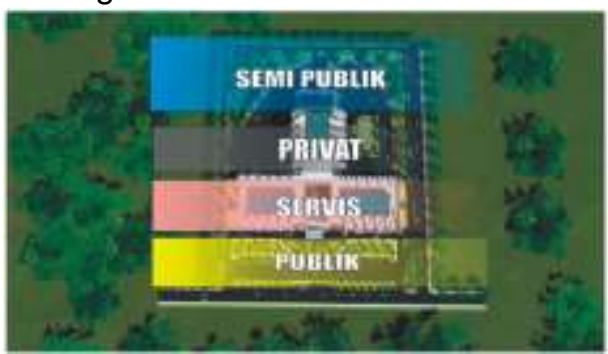

Gambar 5. Analisis PenzoninganbApartemen (Sumber : Analisis Penulis, 2020) 
Pembagian zona/penzoningan pada kawasan sangatlah diperlukan agar dapat menentukan tata letak bangunan yang bersifat publik, semi publik dan privat. Adapun pertimbangan dari penzoningan adalah seperti gambar di atas dimana terdiri dari Zona Privat, Zona Semi Publik dan Zona Publik.

5. Pedestrian

Jalur pedestrian memiliki jalur tersendiri sehingga tidak mengganggu pengguna jalan yang menggunakan kendaraan, yaitu dengan adanya pedestrian bagi pejalan kaki dan ramp bagi penyandang cacat.

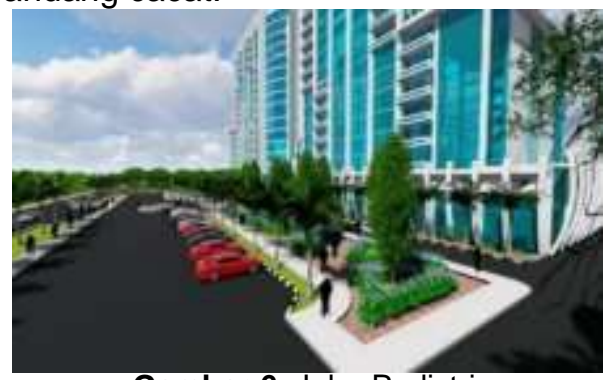

Gambar 6. Jalur Pedistrian

(Sumber: Analisis Penulis, 2019)

\section{Landscape}

\section{1) Soft Material}

Di sekeliling bangunan apartemen diselesaikan dengan penataan lansekap, terutama vegetasi. Vegetasi merupakan elemen hijau dalam kawasan dan memegang peranan penting dalam ekologis lingkungan. Fungsi vegetasi pada tapak antara lain:

\section{a) Pengarah}

Tatanan vegetasi membentuk jalur/path yang mengarahkan pengunjung terutama pejalan kaki menuju bangunan atau obyek menumental dalam tapak. Vegetasi ini juga dapat mengarahkan jalur untuk jogging (joggingtrack)

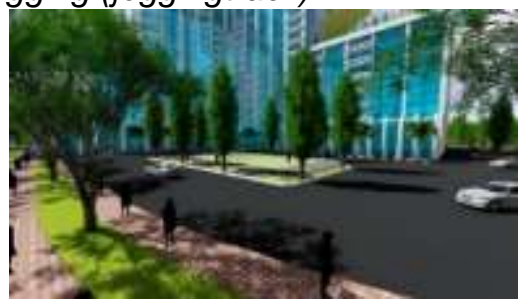

Gambar 7. Palm Raja Sebagai Vegetasi Pengarah b) Peneduh (Sumber: Analisis Penulis 2019)

Vegetasi dapat menaungi pengunjung yang berkunjung di apartemen ataupun yang datang berbelanja Untuk jenis vegetasi ini dipilih mahoni, flamboyan, dan trembesi.

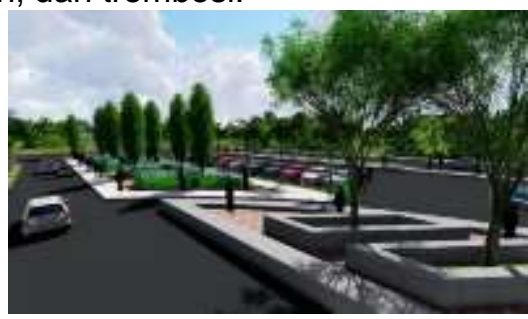

Gambar 8. Trambesi dan flamboyan Sebagai Peneduh (Sumber: Analisis Penulis 2019)

\section{c) Penghias}

Vegetasi juga dapat berfungsi untuk Untuk menambah keindahan di dalam tapak, ditanami beberapa jenis bunga seperti bougenvil dan asoka.

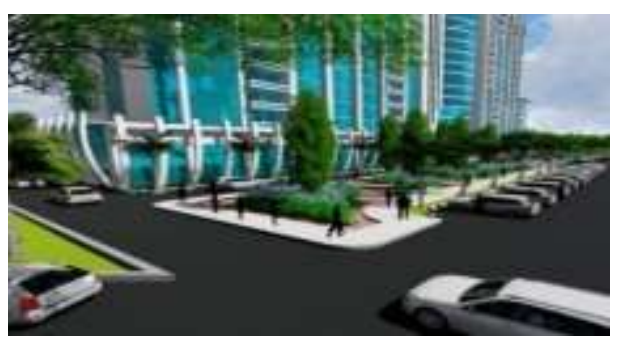

Gambar 9. Bougenvil dan Asoka sebagai estetika (Sumber: Analisis Penulis 2019)

d) Reduksi kebisingan

Tapak yang berada tepat pada jalur utama kendaraan mengakibatkan tingkat kebisingan disekitarnya tinggi. Oleh sebab itu dilakukan penambahan vegetasi yang telah ada di sekitar tapak untuk mereduksi kebisingan dari luar tapak.

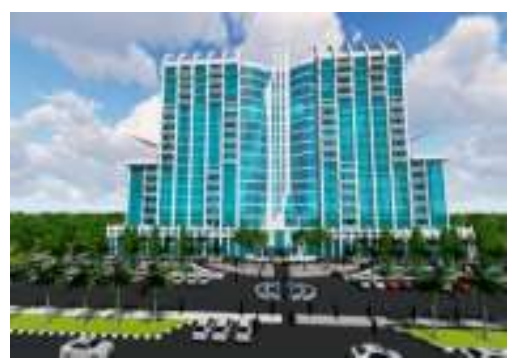

Gambar 10. Trambesi dan palem Sebagai pengarah dan peredam kebisingan

(Sumber: Analisis Penulis 2019)

e) Ekologis

Vegetasi jenis trembesi membantu mengurangi polusi dan memberikan kesan segar dan nyaman bagi pengunjung yang berada di luar Apartemen

f) Pembatas dan penutup

Vegetasi juga dapat berfungsi sebagai pembatas pada sisi banguanan. Sebagai tanaman pembatas menggunakan tanaman jenis perdu rendah yaitu asoka. Dan untuk vegatasi penutup tanah (ground cover) menggunakan rumput kaki gajah.

2) Hard Material

a) Lapangan tenis sebagai sarana olah raga bagi penguna Apartemen

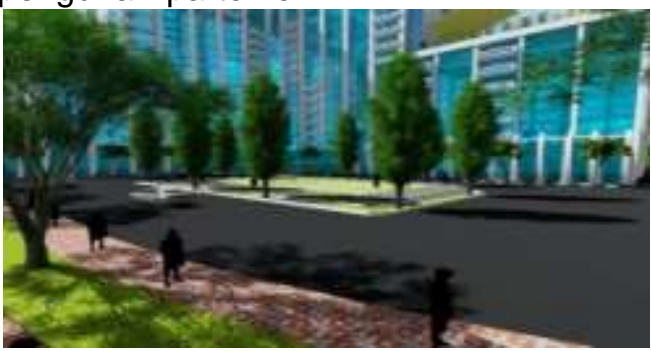

Gambar 11. Lapangan Tenis (Sumber: Analisis Penulis, 2019) 
b) Joging track dan kolam sebagai fasilitas penunjang bagi pengguna apartemen

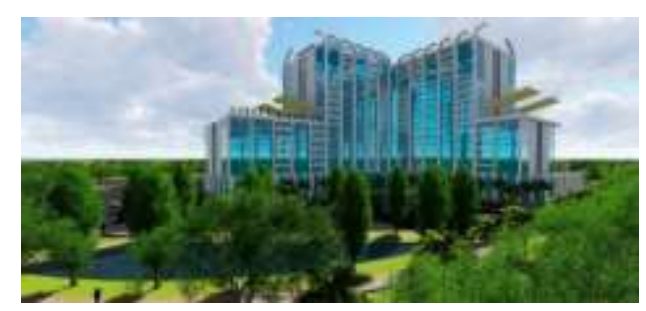

Gambar 12. Kolam dan Joging Track (Sumber: Analisis Penulis 2019)

c) Kolam renang sebagai fasilitas penunjang bagi pengguna Apartemen

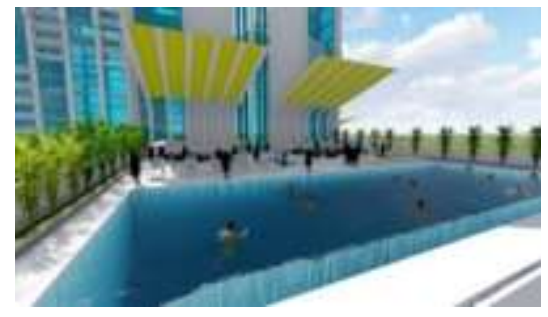

Gambar 13. Kolam Renang

(Sumber: Analisis Penulis 2019)

d) Paving blok digunakan sebagai joging track, pedestrian, sirkulasi pejalan kaki masuk dan keluar tapak.

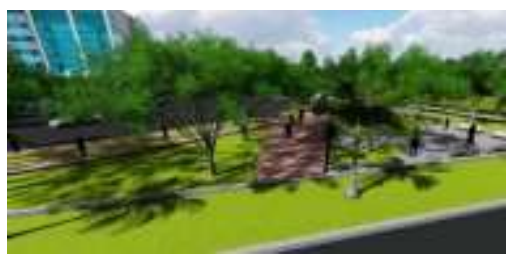

Gambar 14. Paving Block

(Sumber: Analisis Penulis 2019)

e) Aspal digunakan pada jalur kendaraan roda dua dan roda empat. diletakkan di sepanjang jalan dan jalur pedestrian.

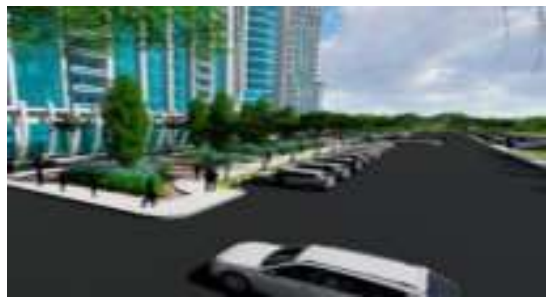

Gambar 15. Aspal

(Sumber: Analisis Penulis 2019)

f) Bangku taman

Bangku taman dapat dibuat dari beton, plastik atau kayu.

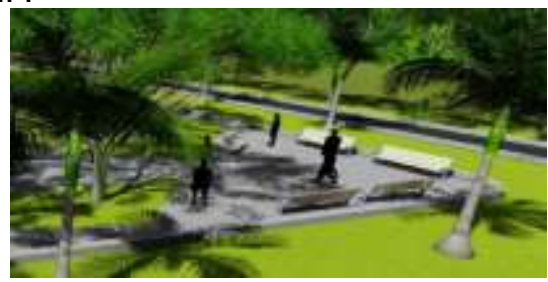

Gambar 16. Bangku Taman (Sumber: Analisis Penulis 2019) g) Air Mancur

Agar taman tidak terkesan monoton dari vegetasi maka air mancur ditempatkan di area taman yang luas. Air mancur digunakan untuk menghiasi ruang luar, mereduksi panas, memfilter polusi udara dan meredam kebisingan.

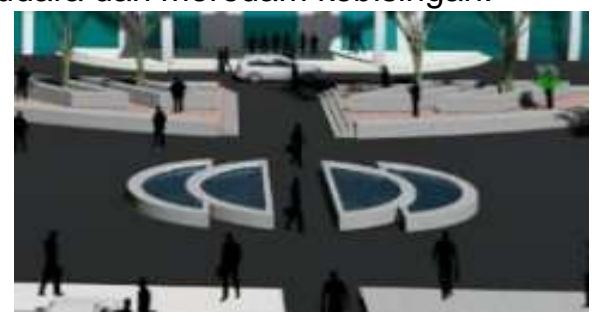

Gambar 17. Air Mancur

(Sumber: Analisis Penulis 2019)

Tabel 1 Perhitungan Besaran Ruang

\begin{tabular}{|c|c|c|}
\hline NO & KELOMPOK RUANG & LUAS \\
\hline 1 & Kelompok Ruang Akomodas & unian \\
\hline & $\begin{array}{l}\text { a. Tipe Satu Ruang Tidur } 41 \\
\text { unit }\end{array}$ & $2905 \mathrm{M}^{2}$ \\
\hline & $\begin{array}{l}\text { b. Tipe Dua Ruang Tidur } 81 \\
\text { unit }\end{array}$ & $5733 \mathrm{M}^{2}$ \\
\hline & $\begin{array}{l}\text { c. Tipe Tiga Ruang Tidur } 79 \\
\text { unit }\end{array}$ & $8996 \mathrm{M}^{2}$ \\
\hline
\end{tabular}

2 Kelompok Ruang Penerimaan (Front Office) a. Lobby 42,274 $\mathrm{M}^{2}$

3 Kelompok Ruang function Room
a. Ruang Serba Guna
$362,4 \mathrm{M}^{2}$

4 Kelompok Ruang Makan dan Minum (Food and Beverage)
a. Coffea Shop/Kafetaria
$102,5 \mathrm{M}^{2}$
b. Bar
91,7 $\mathrm{M}^{2}$
c. Restoran
373,2 $\mathrm{M}^{2}$

5 Kelompok Ruang Cuci dan Tata Graha (Laundry and Housekeeping)
a. laundry
$107,7 \mathrm{M}^{2}$

6 Kelompok Ruang Fasilitas Karyawan ( Empolyee Fasility)
a. Pengelola
$211,9 \mathrm{M}^{2}$
b. Ruang Karyawan $230 \mathrm{M}^{2}$

7 Kelompok Ruang Mekanikal dan Elektrikal serta Area Servis
a. Ruang Mekanikal dan Elektrikal serta ruang $253,06 M^{2}$ Kelompok Servis Area

8 Kelompok Fasilitas Penunjang
a. Shopping Area
$286,02 M^{2}$
b. Fasilitas Penitipan Anak
$160 \mathrm{M}^{2}$ dan Bayi

9 Kelompok Fasilitas Olahraga dan

Rekreasi160 $\mathbf{M}^{2}$

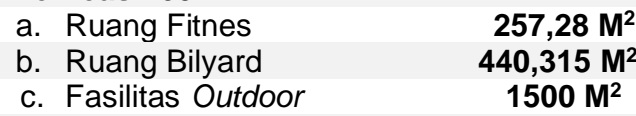

Kelompok Fasilitas Parkir

a. Fasilitas Parkir TOTAL

SIRKULASI $30 \%$ TOTAL LUAS

2213,7 $\mathrm{M}^{2}$

35 609,05 M ${ }^{2}$

$10.682,71 \mathrm{M}^{2}$

46291,76 $\mathrm{M}^{2}$

(Sumber: Analisis Penulis, 2019)

Luas Kawasan Apartemen yang digunakan adalah $20.000 \mathrm{M}^{2}(2,5 \mathrm{Ha})$ dimana perbandingan KDB yang digunakan adalah $40 \%$ Building 
Coverage dan $60 \%$ Open Space (Diperuntukan RTH, sirkulasi jalan, dan pedestrian).

Dengan perbandingan tersebut dapat diketahui luas tapak yang terbangun dan tidak terbangun.

Luas tapak yang terbangun (BC) yaitu: $40 \% \times$ $25.000 \mathrm{M}^{2}=18516,71 \mathrm{M}^{2}$

Luas tapak yang tidak terbangun (OS) yaitu: $60 \% \mathrm{x}$ $25.000 \mathrm{M}^{2}=\mathbf{2 7 7 7 5 , 0 6} \mathbf{M}^{2}$

\section{Bentuk Dan Tampilan Bangunan}

Pendekatan bentuk bangunan yang digunakan dalam mendapatkan bentuk bangunan memiliki keterkaitan dengan fungsi bangunan yaitu dengan konsep modern Filosofi bentuk dasar bangunan mengambil bentuk jangkar kapal. Secara umum makna jangkar adalah simbol pengharapan hidup diumpamakan ibarat sebuah kapal. Kita mengarungi laut kehidupan yang tidak selalu tenang. Akan ada riak, gelombang, angin kencang dan badai yang sewaktu-waktu menerpa. Seperti kapal, kita juga memerlukan jangkar untuk menahan kita dari terpaan ombang atau gelombang kehidupan.
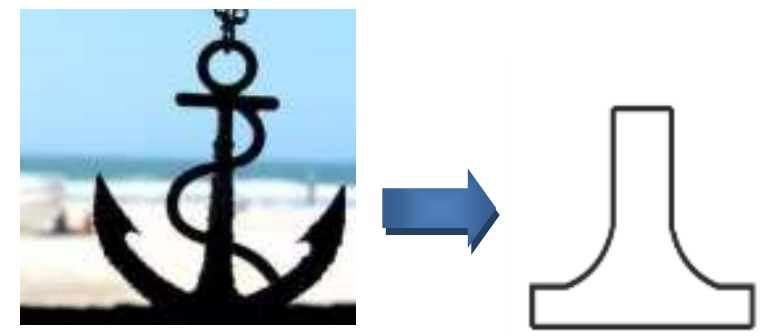

Gambar 18. Bentuk Bangunan (Sumber: Analisis Penulis 2019)

Konsep fasad yang diambil untuk bangunan yaitu dari bentuk rangka kapal yang menjadi struktur terkokoh dari sebuah kapal, dikombinasikan dengan ombak yang diisi dengan bentuk gelembung air yang ditranformasi menjadi bentuk heksagonal. Dengan makusd bangunan ini melambangkan nuansa keikhlasan dan pengharapan

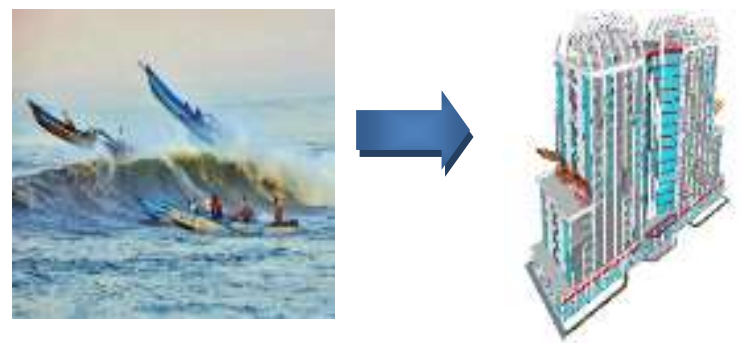

Gambar 19. Bentuk Tampilan Bangunan (Sumber: Analisis Penulis 2019)

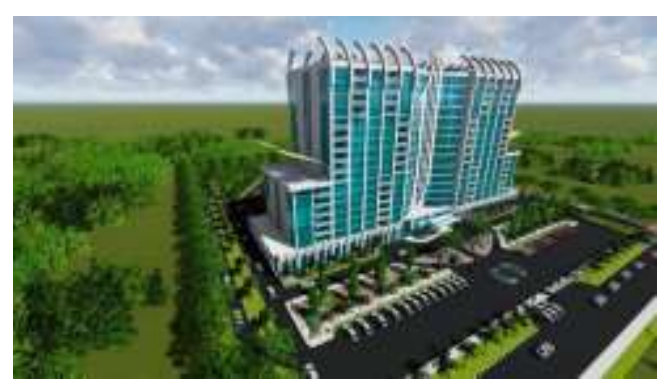

Gambar 20. Gambar Perspektif Bangunan Apartemen (Sumber: Analisis Penulis 2019)

8. Aspek Kenyamanan Dalam Ruang

A. Sistem pencahayaan Alami dan Buatan

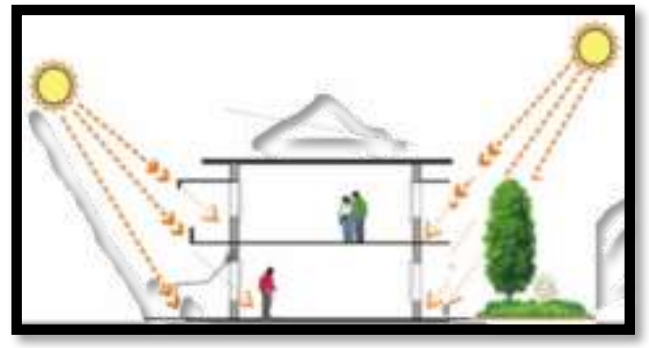

Gambar 21. Pemanfaatan Pencahayaan Buatan (Sumber: Analisis Penulis, 2019)

Sistem pencahayaan dalam apartemen ini sebisa mungkin menggunakan pencahayaan alami jika siang hari dengan menggunakan jendela dan membuat bukaan untuk daerahdaerah yang mendapatkan cahaya maksimal. Dan untuk malam hari menggunakan lampu yang tingkat konsumsi energinya sangat rendah.

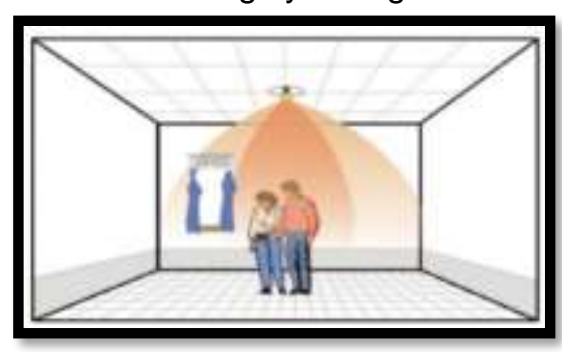

Gambar 22. Pemanfaatan Pencahayaan Buatan (Sumber: Analisis Penulis, 2019)

B. Sistem Penghawaan Alami dan Buatan

Sistem penghawaan pada Gedung Apartemen ini ini sebisa mungkin menggunakan penghawaan alami, khususnya pada ruang-ruang umum.

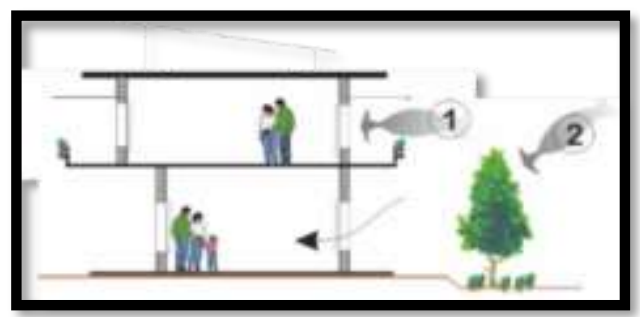

Gambar 23. Sistem Penghawaan Alami (Sumber: Analisis Penulis, 2019) 
Sedangkan untuk ruang kerja, dan kamarkamar menggunakan penghawaan buatan yaitu menggunakan AC (Air Conditioner).

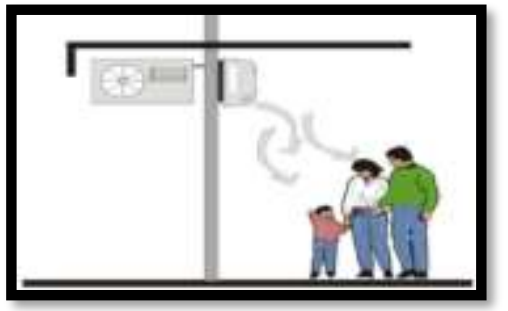

Gambar 24. Pemanfaatan Penghawaan Buatan (Sumber: Analisis Penulis, 2019)

\section{Konsep Material Dan Modul Struktur Bangunan}

a. Material Struktur Yang Digunakan

Struktur dan material yang digunakan dalam Apartemen ini adalah sebagai berikut :

b. Sub Struktur

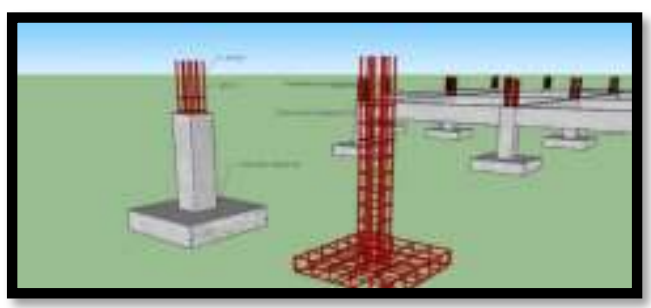

Gambar 25. Pondasi Poer Plat

(Sumber: Analisis Penulis 2019)

Sistem Sub struktur yang digunakan adalah pondasi poer plat, dan pondasi garis, karena bangunan cuman memiliki dua lantai dan keadaan tanah kuat daya dukungnya. Diperhitungkan sistem struktur ini mampu menahan beban vertikal, lateral dan beban gempa.

c. Pondasi Tiang Pancang

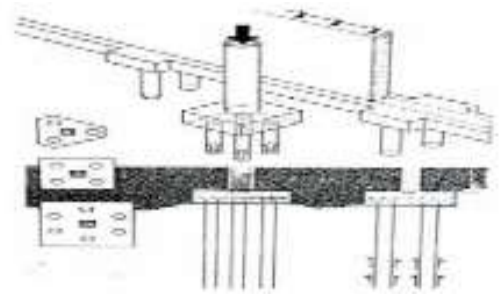

Gambar 26. Pondasi Tiang Pancang (Sumber : Ching, 2008:88)

\section{d. Super Struktur}

Sistem super struktur yang digunanakan dalam Apartemen ini adalah sistem rangkaian balok utama dan balok anak yang ditopang dengan kolom. Penggunaan sistem ini untuk mendapatkan dimensi ruang yang diharapkan dengan pemakaian bahan yang cukup hemat serta pelaksanaan yang cukup mudah. Material yang digunkan adalah beton bertulang.

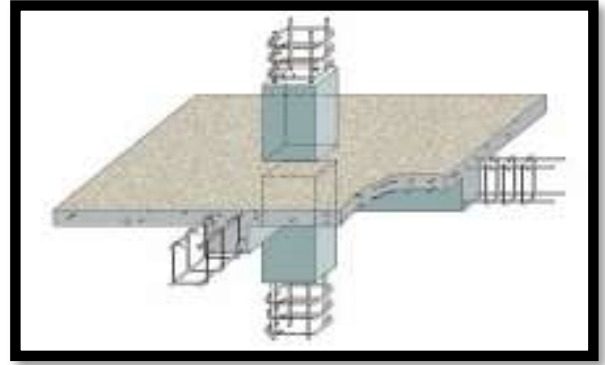

Gambar 27. Rangka Balok

(Sumber: Analisis Penulis 2019)

\section{e. Modul Struktur}

Modul struktur digunakan untuk mempercepat dan mempermudah proses pembangunan dan efektifitas ruang bangunan. Adapun kriteria pemilihan modul adalah sabagai berikut:

1. Sesuai dengan sistem struktur yang digunakan

2. Mampu mendukung bentangan yang besar

3. Standar gerak manusia

4. Layout dan ukuran perabot, dan

5. Fungsi bangunan

\section{Utilitas Bangunan}

A. Sistem Distribusi Air Bersih

Sumber air bersih yang digunakan dalam Apartemen ini yang direncanakan adalah terdiri dari 2 yaitu:

\section{Air Yang Bersumber dari PDAM}

Sistem penyaluran air bersih dari PDAM adalah air telebih dahulu ditampung pada sebuah reservoir bawah tanah, kemudian dipompa ke reservoir yang letaknya di atas bangunan (lebih tinggi dari unit pengguna air pada bangunan), dan langkah selanjutnya adalah mendistribusikan air ke unit-unit pengguna air dengan menggunakan pompa booster.

\section{Air Yang Bersumber Dari Sumur Bor}

Proseskerja system ini adalah air yang bersumber dari sumur bor akan ditampung dalam reservoir bawah, air selanjutnya dipompa menggunakan pompa hidrolik ke reservoir atas, kemudian dipompa dengan pompa booster ke unit pengguna air.

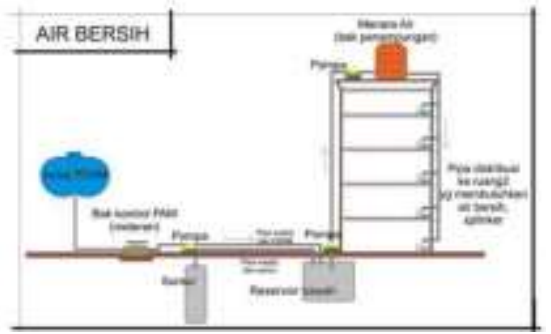

Gambar 28. Skema Penyediaan Air Bersih (Sumber: Analisis Penulis 2019)

B. Sistem Distribusi Air Kotor

Sistem yang digunakan untuk pembuangan air kotor yaitu:

1. Dengan System Riol Kota

Air kotor yang dibuang dengan menggunakan cara ini adalah air bekas yang berasal dari floor drain, wastafel, tempat cuci piring, atau tempat lain dalam bangunan yang pada dasarnya air bekas ini bukan kotoran padat. 


\section{Dengan System Septic Tank dan Resapan}

Air kotor dari bangunan akan dialirkan ke septic tank dan di dalam septic tank tersebut terjadi pengolahan dan penguraian oleh bioorganic. Kemudian hasil pengolahan dalam septic tank akan dialirkan dengan menggunakan pipa overflow ke sumur resapan. Oleh sebab itu penempatan antara septic tank, sumur resapan dengan sumur air bersih harus lebih jauh. Air kotor diresapkan melalui sumur resapan ke dalam tanah, dan jika sumur resapan sudah penuh maka akan dialirkan ke roil kota.

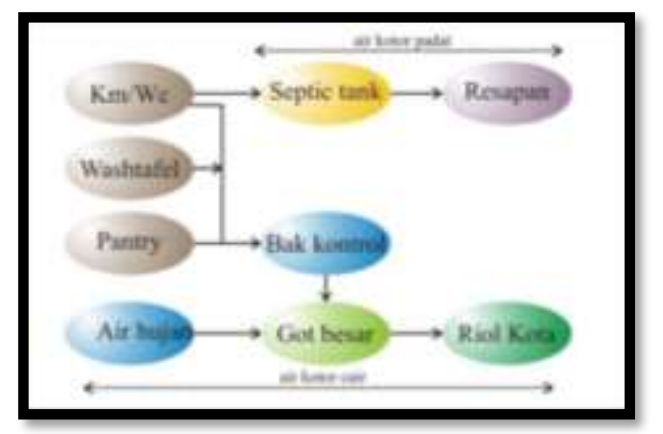

Gambar 29. Distribusi Air Kotor (Sumber: Analisis penulis, 2019)

\section{Sistem Persamapahan}

Adapun dasar pertimbangan sistem pembuangan sampah yaitu:

a. Kemudahan pengontrolan.

b. Tidak mengganggu pemandangan.

c. Kemudahan pengangkutan.

d. Tidak menyebabkan polusi udara Sistem pembuangan sampah dapat digolongkan secara:

1. Secara horizontal, yaitu dengan penempatan lori atau tempat sampah ditiap lantai (tempat-tempat tertentu) yang mudah diangkut dan dibersihkan.

2. Secara vertikal, yaitu sampah disalurkan melalui shaft khusus pembuangan sampah dan diangkut oleh truk sampah ke Tempat Pembuangan Akhir (TPA).

D. Sistem Jaringan Elektrikal

Jenis sistem jaringan elektrikal pada bangunan

ini terdiri dari dua yaitu sumber listrik dari PLN dan sumber listrik dari generator set (genset). Penggunaan listrik yang berasal dari PLN langsung pada bagian-bagian yang membutuhkan listrik.

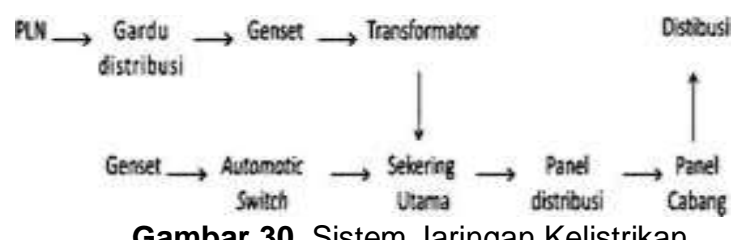

Gambar 30. Sistem Jaringan Kelistrikan (Sumber: Analisis penulis, 2019)

\section{a. Pencegahan pasif}

Alat Bantu evakuasi merupakan sarana penunjang dalam upaya penyelamatan pelaku kegiatan, sehingga mempermudah evakuasi serta meningkatkan keamanan terhadap bahaya kebakaran. Sarana penunjang tersebut terdiri dari: 1. Penerangan darurat

Pemasangan lampu diletakkan pada tangga darurat, jalan penghubung atau jalan yang dipergunakan oleh manusia pada saat kebakaran.

2. Sumber daya listrik darurat

Sumber listrik ini dipergunakan untuk mengaktifkan semua peralatan bantu evakuasi.

b. Pencegahan aktif

Pencegahan bahaya kebakaran yang terjadi di luar bangunan menggunakan Pilar Hydrant yang diletakkan pada halaman.

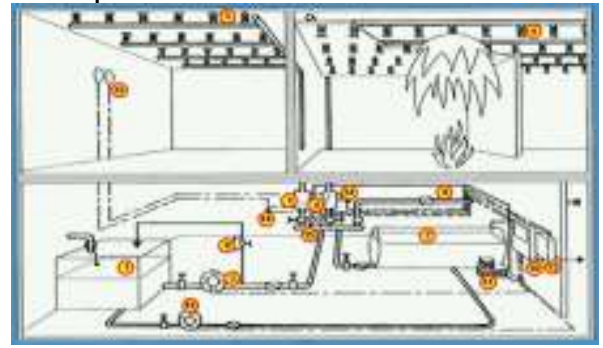

Gambar 31. Pencegahan kebakaran dari luar bangunan (Sumber: Juwana, 2005)

\section{Fire Alarm system}

Penggunaan alat ini untuk memberitahukan apabila terjadi kebakaran.

2. Fire Hidrant System

Yaitu sebuah kotak yang berisi selang dengan jarak maksimal $35 \mathrm{~m}$ satu dengan yang lainnya, dengan panjang selang $30 \mathrm{~m}$ dan jarak semprotan air $5 \mathrm{~m}$.

3. Alat pemadam kebakaran ringan

Alat ini berupa tabung-tabung gas zat arang atau serbuk anti api dan dilengkapi dengan alat penyemprot. Untuk setiap area seluas $100 \mathrm{~m} 2$ disediakan satu alat tersebut.

c. Sistem keamanan dalam bangunan ini dilakukan dengan menyediakan fasilitas pengamatan dan pencegahan, antara lain:

1. Sistem CCTV (Central Circuit Television), untuk memonitor segala penjuru bangunan yang diperkirakan dapat menjadi tempat terjadinya kriminalitas, seperti pencurian dan sebagainya.

2. Sistem alarm, yang diaktifkan pada waktu-waktu tertentu untuk melindungi hasil karya yang dipajang atau dipamerkan dalam bangunan.

3. Satuan pengamanan (Satpam) yang bertugas 24 jam.

\section{E. SistemKeamanan Bangunan}

1. Sistem pencegahan dan penanggulan bahaya kebakaran. 


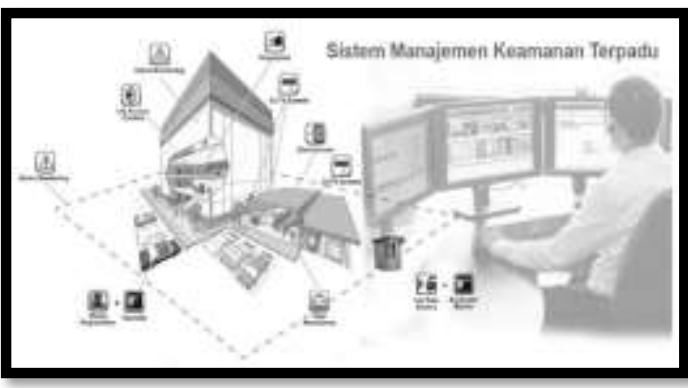

Gambar 32. Alat Pengaman Pada Pencurian (Sumber: Analisis Penulis, 2019)

d. Sistem penamgkal petir

Sistem penangkal petir digunakan pada bangunan untuk melindungi dari bahaya ledakan dan kebakaran yang di timbulkan oleh sambaran petir. Sistem penangkal petir terdiri dari:

a. Sistem konvensional, yaitu sistem faraday dan sistem franklin.

b. Estetika, utamamnya pada penampilan bangunan dalam pemeliharaan sistem penangkalan petir yanh umumnya digunakan adalah sistem faraday, yang terdiri dari :

1. Alat penerima setinggi $150 \mathrm{~cm}$ pada setiap jarak 20 meter

2. Kawat mendatar

3. Pertahanan

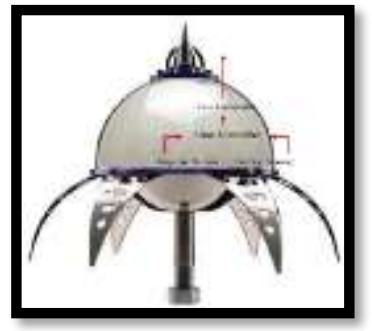

Gambar 33. System pengangkal petir (Sumber: Analisis Penulis, 2019)

Sistem ini merupakan teknologi terkini, sering juga dikenal dengan sistem payung. Untuk pemasangan penangkal petir ini tidak terlalu rumit, cukup 1 kabel penghantar untuk setiap 1 penangkal petir.

\section{KESIMPULAN}

Berdasarkan sifat pelayanannya dalam bidang kegiatan permukiman perkotaan, perkantoran, perdagangan, jasa dan pariwisata (bangunan komersial) perencanaan Apartemen Kota Kendari dengan melakukan penilaian pemilihan site dan memperhatikan beberapa kriteria penentu, maka lokasi yang paling tepat untuk perencanaan apartemen di Kota Kendari berada di Kecamatan Kadia.

Tata ruang apartemen dapat dibagi menjadi tiga kelompok yakni kelompok ruang publik, servis, dan privat. Semakin tinggi kemampuan perekonomian keluarga, tuntutan penyediaan ruang untuk menampung masing-masing kegiatan secara khusus menyebabkan luasan tempat menjadi berkembang, namun di sisi lain pertimbangan efisiensi dan keterbatasan ruang memaksa penghuni untuk mencari solusi tata ruang yang simple namun dapat menampung bermacammacam kegiatan yang berlangsung di Apartemen dengan kualitas yang tetap terjaga.

Perancangan Pembangunan Apartemen di Kota Kendari dengan pendekatan arsitektur modern adalah sebuah rancangan untuk membangun sebuah Apartemen terencana di kawasan-kawasan yang memenuhi berdirinya suatu bangunan Apartemen yang memiliki fasilitas penunjang yang baik dan layak huni dan berada di seputar tapak/lokasi, yang perancangan pembangunannya menggunakan pendekatan desain Arsitektur Modern.

\section{DAFTAR PUSTAKA}

Ching, D. K. Francis, 2000, Arsitektur, Bentuk, Ruang dan Susunannya, ed. ke-2. Terj. Nurrahman Tresani Harwadi, Erlangga, Jakarta.

Indonesia, P. R., \& Indonesia, P. R. (1985). Undang Undang No. 16 Tahun 1985 Tentang: Rumah Susun. Sekretariat Negara. Jakarta.

Juwana Jimmy, S. (2005). Sistem Bangunan Tinggi. Erlangga. Jakarta.

Neufert, Ernst. 1999, Data Arsitek, Jilid 2, Erlangga, Jakarta

Paul, S. (1967). Apartments: their design and development. Reinhold Publishing Company.

Poerwadarminta W.J.S. (1991) Kamus Umum Bahasa Indonesia. Pusat Pembinaan dan Pengembangan Bahasa. PN. Balai Pustaka. Jakarta

Silalahi, U. (2018). Metodologi analisis data dan interpretasi hasil untuk penelitian sosial kuantitatif. 